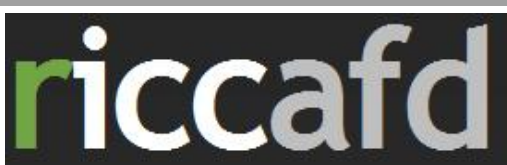

Revista Iberoamericana de Ciencias de la Actividad Física y el Deporte

\title{
INYECCIONES LOCALES MULTIPUNTUALES CON CORTICOSTEROIDE PARA EL SÍNDROME DE ESTRÉS TIBIAL MEDIAL: UN NUEVO ENFOQUE
}

\section{LOCAL MULTIPUNCTUAL CORTICOSTEROID INJECTIONS FOR MEDIAL TIBIAL STRESS SYNDROME: A NOVEL APPROACH}

\author{
Medina I, Jurado A, Magee DJ, Vas J \\ Medina I. PT, RN, Larios Sportsmedicine Rehabilitation Center, Malaga, Spain. \\ Jurado A. PT, RN, Professor, Department of Psychiatry and Physical Therapy, University of Malaga, Malaga, Spain \\ Magee DJ. PT, PhD, Professor, Department of Physical Therapy, University of Alberta, Edmonton AB, Canada. \\ Vas J. MD, PhD, Chief Medical Officer, Pain Treatment Unit, Dos Hermanas, Seville, Spain - Cooperative Research Network (IRYSS), Spain. \\ Medina, I correo electrónico: imp@uma.es \\ Código UNESCO: 3213.11 Fisioterapia \\ Clasificación Consejo de Europa: 14. Fisioterapia y rehabilitación \\ Recibido el 6 de septiembre de 2013 \\ Aceptado el 30 de octubre de 2013
}

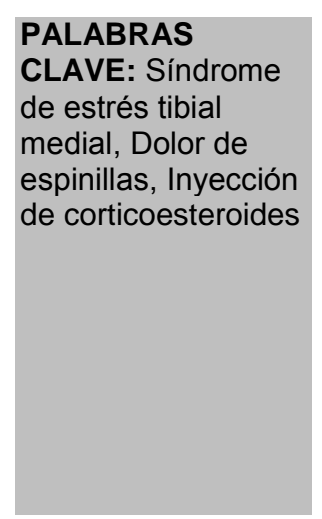

\section{KEY WORDS:}

Medial tibial stress syndrome,

Shin splint, Corticosteroid injection

\section{RESUMEN}

El síndrome de estrés medial de la tibia (SEMT) constituye una de las afecciones más comunes del miembro inferior. Los resultados obtenidos con terapias convencionales en esta patología son dispares. La infiltración local de corticoides ha mostrado producir efectos favorables en el tratamiento de diversos problemas musculoesqueléticos. El efecto de la infiltración local multipuntual de un corticoide en combinación con un anestésico se estudió en 47 pacientes (29 hombres y 18 mujeres, con una edad media de 23.8) afectos de SEMT. La consulta directa y el examen físico se emplearon para valorar los resultados. Los pacientes fueron valorados una vez a la semana tras la primera aplicación durante las primeras cuatro semanas y 3 meses después del tratamiento. El nivel de actividad en ausencia de síntomas fue registrado en cada caso. Los resultados de la infiltración multipuntual se determinaron comparando los niveles de actividad en ausencia de síntomas preintervención y posintervención y la capacidad de los deportistas para volver a los niveles de actividad presintomáticos. Los resultados sugieren que este tratamiento reduce el tiempo de recuperación y mejora los resultados funcionales

\section{ABSTRACT}

Medial stress tibial syndrome (MTSS) has been and remains one of the most common pathologic conditions of the lower extremity. The results of conventional therapies for this condition have been inconsistent. Local corticosteroid injection has been shown to have favourable effects in treating musculoskeletal disorders. The effect of local multipunctual injections of a corticosteroid combined with an anaesthetic was studied in 47 patients (29 male and 18 female subjects, with an average age of 23.8 years) with MTSS. Direct consultation and examination was used to assess outcome. Patients were evaluated once a week after first injection for the first 4 weeks, and 3 months after treatment as well. Level of symptoms-free activity was recorded for each patient. The outcomes of the multipunctual injections were determined by comparing preintervention and posintervention level of symptoms-free activity and ability of the athletes to return to presymptom levels of exercise. The results suggest that the treatment reduces the recovery time and improves functional outcomes. 


\section{INTRODUCTION}

Tibial stress injuries represent a significant cause of exercise-induced leg pain. Medialtibial stress syndrome (MTSS) is a common complaint among runners that can become a debilitating injury. Affecting predominantly female athletes(1, 2 ), it accounts for between $13.2 \%$ and $17.3 \%$ of all running injuries(3). It has been considered as the fifth most common injury and, when combined with tibial stress fracture, would be the third most common injury behind only patellofemoral pain syndrome and iliotibial band friction syndrome(4). Certain studies report up to a $35 \%$ incidence of MTSS in actively training military recruits and $13 \%$ in civilian runners(5). Bennett looked at high school cross-country runners over the course of a season and found $12 \%$ developed MTSS (19\% in females)(6).

MTSS represents a multifactorial etiologic disorder in which the most evident characteristic is recurrent pain over the frontal or posteromedial aspect of the middle and lower third of the tibia (7-10). It is a condition which begins with an insidious onset. It may be seen unilaterally, although more frequently both legs are affected, with one leg being more severe than the other. It is an extremely common complaint among runners that becomes progressively worse with repetitive impact activities, frequently leading to athletes having to curtail their activity(11-14). MTSS is clearly located along the shin with little or no radiation. The current thinking regards it as a chronic periosteal irritation due to fascial traction, usually secondary to prolonged exercise (ie. an overuse injury, especially when eccentric work is performed)(9, 15-17), since inflammatory changes have been found in the insertion of the periosteum, fascia or muscle, or both(18-20).

Currently, little evidence exists in the literature to support the use of the most commonly applied interventions for the treatment of MTSS(13). Traditional treatments include local cryotherapy, stretching and strengthening of gastrocnemius-soleus musculature, the use of nonsteroidal anti-inflammatory drugs (NSAIDs), iontophoresis with calcium or corticosteroids, modification of training regimens, orthotic devices to correct for biomechanical abnormalities, and rest(10, 21 26).

Local corticosteroid injection has been shown to have favourable effects in alleviating pain, swelling and dysfunction in musculoskeletal disorders(27-31), even when compared to more conservative treatments in a short term follow up assessment(32). Soft-tissue injuries such as tendinopathies or sprains have been effectively treated with this modality. As an inflammatory condition affecting soft tissues, MTSS can potentially be treated by local cortisone administration. To the authors' knowledge, the application of multipunctual corticosteroid injections on MTSS has not been previously reported.

We hypothesize that local multipunctual corticosteroid injections applied to the posteromedial aspect of the middle and lower third of the tibia, at the soleus insertion, could be helpful when treating MTSS.

\section{MATERIAL AND METHODS}

In this case series study, over a 14-monthperiod between 2001 and 2003, a convenience sample of 47 patients with MTSS referred to the clinic were examined and treated by two of us (AJ and IM). This sample was $100 \%$ of the subjects referred with MTSS during this time period, each of whom signed an informed consent form reiterating the basic procedures and intent of the study and warning of any potential risks as a result of participation. All of them completed a baseline history form that addressed the patients' age, gender and level of sports participation.

Physical examination. MTSS was defined as recurrent pain over the frontal or posteromedial aspect of the middle and lower third of the tibia, exacerbated with specific, local palpation and weight-bearing repetitive activities $(7,8,33,34)$. The presence of clinical evidence of compartment syndrome or muscle herniation, or a positive percussion test on the tibia were considered causes of exclusion. Patients were examined by a licensed physical therapist with 10 to 22 years of clinical experience to determine if he or she met the criteria for MTSS. The location of pain and tenderness and the duration of symptoms were also recorded.

Tibial soft tissue traction test (Figure 1) and tender area palpation were performed and recorded in each case. Early in this series, all patients were conservatively treated during the first nine sessions -2 weeks- (Table 1). After 9th session the first injections were given. Corticosteroid injections were considered and discussed only after noninvasive treatment was deemed to have failed by both the therapists and the patient. In this series, no patient received the injection before a minimum of 9 sessions of treatment (range, 9 to 11).

Rev. Ib. Cᄃ. Act. Fis. Dep. 


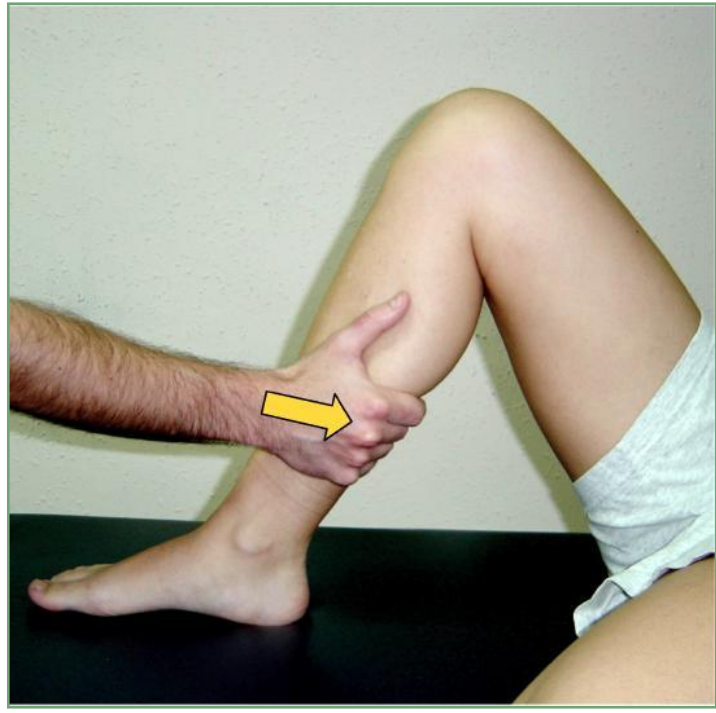

Figure 1. Soft-tissue traction test.

Table 1. Conservative Treatment Protocol for MTSS.

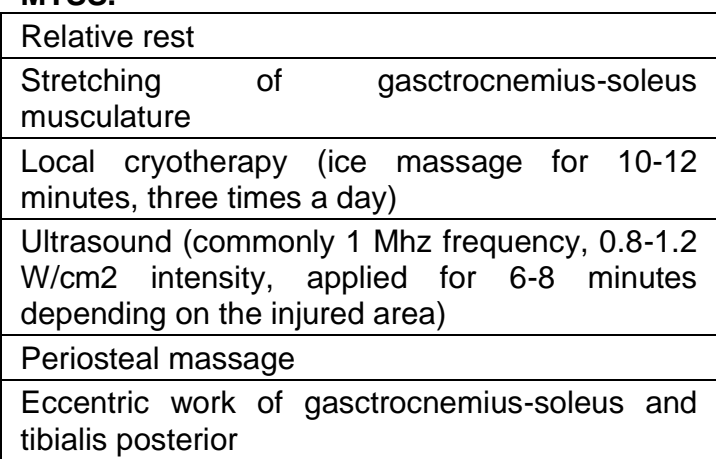

Corticosteroid injection technique. Before injection, the area was scrubbed with povidone iodine. A careful palpation of the tender area and a positive soft tissue pain provocation test were necessary in order to determine correct needle placement (Figure 2), in the soleus fascial origin.

The administered dose of the injection was $3 \mathrm{cc}$, in equal shares betamethasone (celestone cronodose $\AA$ ) and local anaesthetic (scandinibsa $\AA$ ). Six or seven low penetration injections of $0.4-0.5 \mathrm{ml}$. each were performed, no more than $4-5 \mathrm{~mm}$ deep using thin board needles $(0.4 \times 25 \mathrm{~mm})$. If a second or third set of injections was necessary they were given one and two weeks after the first injection.

Postinjection regimen. Two days after the first set of injections, sport activity was progressively introduced with the following progression criteria during the first week: general and specific stretching of the injured area; running on a soft Medina I, Jurado A, Magee D」 y Vas ل

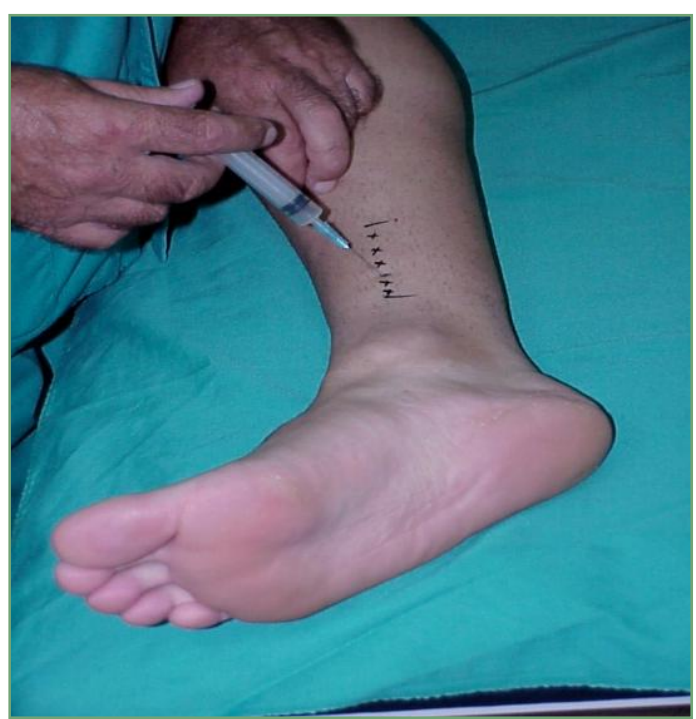

Figure 2. Needle placements when applying multipunctual corticosteroid injections.

surface (for example, grass, sand) for ten minutes; progressive series of runs $(5 \times 60 \mathrm{~m})$ at $80 \%$ of maximum pain free intensity; and local cryotherapy (ice massage for 10-12 minutes, three times a day). The main criterion for returning to sport activities was that the subject be able to perform specific individual activities (e.g. running, high jump, long jump) without pain, or with minimal discomfort (VAS score $<2$ ).

Follow-up evaluation. Direct consultation and examination was used to assess outcome. Posinjection symptoms performing their previous activity were recorded for each patient. We evaluated the patient once a week after first injection for the first 4 weeks, and 3 months after treatment as well in order to assess their level of activity. The outcomes of this injection technique were determined by comparing preintervention and posintervention ability of the athletes to return to presymptom levels of exercise.

\section{RESULTS}

There were 29 male and 18 female subjects, with an average age of 23.8 years (range, 19 to 38 years). The location of pain was as follows: posteromedial distal third, in 42 athletes (89.4\%); posteromedial middle-upper third, in 4 athletes (8.5\%); and posteromedial upper third in just one athlete $(2.1 \%)$.

In 41 subjects $(87.2 \%)$, the pain was bilateral. Six of these patients (12.8\%) had unilateral pain. All of the patients in the series were involved in sports although the majority of patients felt their problem was work related -recreational: 4; amateur: 3; professional: 4; workrelated: 36 .

Rev. lb. Cᄃ. Act. Fis. Dep. 
Inyecciones lacales multipuntuales con corticasteraide para el síndrame de estrés tibial medial: un nuevo enfaque Medina I, Jurado A, Magee D」 y Vas ل

Thirty-eight of the patients $(80.8 \%)$ were runners. In all cases, pain was work-related.

All of the patients included in this study were given at least one series of injections. Thirty-one patients $(65.9 \%)$ received two sets of injections. Twelve $(25.5 \%)$ required a third infiltration to alleviate their symptoms. Those patients demonstrating a larger site of symptoms received more injections but the same amount of medication. Thirty-nine (82.9\%) of 47 treated athletes returned to complete activity with no pain associated with sport activity after four weeks, whereas six of them $(12.8 \%)$ referred minimal discomfort. Two subjects $(4.3 \%)$ returned to sport activity 6 weeks from the beginning of the treatment with minimal discomfort. Four athletes suffered a relapse after three months of training. There were neither device-related problems nor systemic or local complications due to medication.

\section{DISCUSSION}

As both etiology and pathophysiological mechanism of this syndrome are still not well understood, there is no consensus about its management. The recommended physical therapy treatment for MTSS includes rest from specific physical $\operatorname{activity}(7,16,21,24)$, ultrasound(16, 23), phonophoresis(23), iontophoresis with calcium or corticosteroids(23, $25)$, use of oral antiinflamatory medication $(7,21$, 24), stretching of gastrocnemius-soleus musculature $(23,33)$, local cryotherapy $(23,24$, 34 ), orthotic devices(12) or even plaster cast immobilization, and a gradual return to full activity(7). There is a paucity of evidence supporting the use of many of these interventions and none of these treatments by themselves or in combination have been definitively demonstrated to be efficacious(11, $22)$. In certain cases the results of treatment have been very discouraging(35). As an inflammatory condition affecting soft tissues, we hypothesized that MTSS can potentially be treated by local cortisone administration with similar results than other musculoskeletal disorders(27-32). Adverse effects such as postinjection pain or skin atrophy over the injection site, as well as systemic effects vasovagal syncope, hiccoughs, excitement or medication allergy- have been reported(42). The small amount of medication administered(29) in each injection, as well as the combined use of anaesthetic, may be an explanation for the absence of local side-effects when using this multipunctual technique. Five patients (10.6\%) reported slight discomfort and/or tenderness in the injected region, likely due to the impact of multiple needles.

Rev. Ib. CL. Act. Fis. Dep.
The MTSS term was first introduced by Puranen(19) in 1974, who suggested the pain resulted from ischemia of the deep flexor compartment muscles, secondary to an increase in the intracompartimental pressure caused by prolonged exercise and fascial thickening and shortening. This finding was supported by the immediate relief provided by fasciotomy.

However, Puranen's conclusions were later questioned since no relationship between this syndrome and the increase of intracompartimental pressure was demonstrated(18, 36). In 1978, James et al. suggested that the problem -presence of painwas due to injury to the tibialis posterior attachment in this area(12), although subsequent studies $(33,37)$ have demonstrated a more lateral tibial origin for tibialis posterior. In 1982, Mubarak et al. proposed periostitis as the cornerstone of the condition(36), although analysis has shown that periosteal swelling and pain do not always coexist(17). Three years later, Michael and Holder identified the soleus muscle and its investing fascia as the main structures anatomically and biomechanically implicated in the production of this condition, which they named as soleus syndrome(33).

Finally, in 1994, Beck and Osternig provided confirmatory evidence that soleus and flexor digitorum longus were more consistently attached on the symptomatic area, and that the posterior tibial fibers did not insert into the lower third of the lateral tibia and interosseus membrane(37). According to these authors, from an anatomic point of view, treatment modalities should focus on the posteromedial aspect of the middle and lower third of the tibia, that's to say, the soleus insertion.

The diagnosis of MTSS is primarily a clinical one. In our experience, every patient with MTSS has a diffuse region of tenderness along the posteromedial edge of the tibia. This tenderness is generally present in the middle and distal thirds of the tibia, from approximately $12 \mathrm{~cm}$ proximal to the medial malleollus, extending distally to about $4 \mathrm{~cm}$ proximal(11). Several authors have reported that the most common location of pain was the lower third of the posteromedial border of the tibia $(8,33,38)$, although this site may vary depending on sport activity, since different structures may be recruited and stressed(33, 36). Again, clinical findings support what anatomy suggested initially: any local corticoid administration should be proportionally applied along the site of pain. Beck and Osternig(37), as well as James(39), have highlighted the soleus fascia as the main structure that inserts into the whole medial tibial border and is likely to be responsible for the 
Inyecciones lacales multipuntuales can corticasteraide para el síndrame de estrés tibial medial: un nuevo enfaque Medina I, Jurado A, Magee D」 y Vas ل

pain, discarding prior studies that sustained that the tibialis posterior may contribute to this condition(38). One test which the authors found to be useful is one which consists of tissue traction applied by the heel of the examiner's hand along the posteromedial border of the tibia, stretching the soleus fascia. A sharp pain elicited in the location that patients have reported as the most painful area indicates a positive finding. In all 47 patients, this test was positive.

Classically, the surgical intervention most often proposed is subcutaneous fasciotomy together with periosteal cauterisation or soleus disattachment from the tibial medial border(18, 40, 41). These techniques are supposed to release the pressure within the compartment. Since no relationship has been demonstrated between this syndrome and the increase of intracompartimental pressure(36), surgery has rarely been considered as the first option for treatment. Wallenstein, for example, found a complete relief of symptoms in only 5 of the 9 MTSS patients who underwent fasciotomy(18). Nonetheless, when conservative modalities fail, surgery is indicated(33).

These results suggest that a more rapid return to activity and a functional improvement can be achieved through the judicious use of multipunctual corticosteroid injections. The most appropiate corticosteroid, dose, injection volume and injection interval remains unclear(31). The authors assume that corticosteroid injection represents a symptomatic short term treatment that is potentially revocable(31), but may be beneficial in athletes who need to return to competition within 2 weeks, as advocated by Fricker et al(43). Thus, some other conservative measures such as running technique modification, terrain changes, muscle stretching, foot control or orthotic support must be added as needed in order to avoid any relapse(7, 14, 23, 33). Future research to test our hypotheses should include randomized, controlled trials that accurately study pain level and functional response modifications.

\section{REFERENCES}

1. Plisky MS, Rauh MJ, Heiderscheit B, Underwood FB, Tank RT. Medial tibial stress syndrome in high school cross-country runners: incidence and risk factors. J Orthop Sports Phys Ther. 2007 Feb;37(2):40-7.

2. Clement DB, Taunton JE, Smart GW, McNicol

$\mathrm{KL}$. A survey of overuse running injuries.

Physician Sportsmed. 1981;9:47-58.

3. Yates $B$, White $S$. The incidence and risk factors in the development of medial tibial stress syndrome among naval recruits. Am J Sports Med. 2004 Apr-May;32(3):772-80.
4. Taunton JE, Ryan MB, Clement DB, McKenzie DC, Lloyd-Smith DR, Zumbo BD. A retrospective case-control analysis of 2002 running injuries. $\mathrm{Br} J$ Sports Med. 2002 Apr;36(2):95-101.

5. Magnusson $\mathrm{HI}$, Ahlborg HG, Karlsson C, Nyquist F, Karlsson MK. Low regional tibial bone density in athletes with medial tibial stress syndrome normalizes after recovery from symptoms. Am J Sports Med. 2003 Jul-Aug; 31(4):596-600

6. Bennett JE, Reinking MF, Pluemer B, Pentel A, Seaton M, Killian C. Factors contributing to the development of medial tibial stress syndrome in high school runners. J Orthop Sports Phys Ther. 2001 Sep;31(9):504-10.

7. Moore MP. Shin splints. Diagnosis, management, prevention. Postgrad Med. 1988 Jan;83(1):199-200, 3-5, 8-10.

8. Melberg PE, Styf J. Posteromedial pain in the lower leg. Am J Sports Med. 1989 Nov-Dec; 17 (6):747-50.

9. Batt ME. Shin splints--a review of terminology. Clin J Sport Med. 1995;5(1):53-7.

10. Bates $\mathrm{P}$. Shin splints--a literature review. $\mathrm{Br}$ J Sports Med. 1985 Sep;19(3):132-7.

11. Kortebein PM, Kaufman KR, Basford JR, Stuart MJ. Medial tibial stress syndrome. Med

Sci Sports Exerc. 2000 Mar;32(3 Suppl):S27-33.

12. James SL, Bates BT, Osternig LR. Injuries to runners. Am J Sports Med. 1978 Mar-Apr; 6 (2) $: 40-50$.

13. Thacker SB, Gilchrist J, Stroup DF, Kimsey $\mathrm{CD}$. The prevention of shin splints in sports: a systematic review of literature. Med Sci Sports Exerc. 2002 Jan;34(1):32-40.

14. Slocum DB. The shin splint syndrome. Medical aspects and differential diagnosis. Am J Surg. 1967 Dec;114(6):875-81.

15. Schepsis AA, Martini D, Corbett M. Surgical management of exertional compartment syndrome of the lower leg. Long-term followup. Am J Sports Med. 1993 Nov-Dec;21(6):811-7; discussion 7.

16. Clement DB. Tibial stress syndrome in athletes. J Sports Med. 1974 Mar-Apr;2(2):81-5. 17. Batt ME, Ugalde V, Anderson MW, Shelton DK. A prospective controlled study of diagnostic imaging for acute shin splints. Med Sci Sports Exerc. 1998 Nov;30(11):1564-71.

18. Wallenstein R. Results of fasciotomy in patients with medial tibial syndrome or chronic anterior-compartment syndrome. J Bone Joint Surg Am. 1983 Dec;65(9):1252-5.

19. Puranen J. The medial tibial syndrome: exercise ischaemia in the medial fascial compartment of the leg. J Bone Joint Surg Br. 1974 Nov;56-B(4):712-5.

20. Fredericson $M$, Bergman $A G$, Hoffman $K L$, Dillingham MS. Tibial stress reaction in runners. Correlation of clinical symptoms and scintigraphy with a new magnetic resonance

Rev. Ib. Cᄃ. Act. Fis. Dep. 
Inyecciones locales multipuntuales con corticasteraide para el síndrome de estrés tibial medial: un nuevo enfoque Medina I, Jurada A, Magee DJ y Vas ل

imaging grading system. Am J Sports Med. 1995 Jul-Aug;23(4):472-81.

21. Story J, Cymet TC. Shin splints: painful to have and to treat. Compr Ther. 2006 Fall; 32 (3):192-5.

22. Beck BR. Tibial stress injuries. An aetiological review for the purposes of guiding management. Sports Med. 1998 Oct;26(4):26579.

23. Smith W, Winn F, Parette R. Comparative studv using four modalities in shinsplint treatments. J Orthop Sports Phys Ther. 1986;8:77-80

24. Fick DS, Albright JP, Murray BP. Relieving painful shin splints. Physician Sportsmed. 1992;20:105-13.

25. Delacerda FG. Iontophoresis for treatment of shinsplints. J Orthop Sports Phys Ther. 1982;3:183-5.

26. Andrish JT, Bergfeld JA, Walheim J. A prospective study on the management of shin splints. J Bone Joint Surg Am. 1974 Dec;56(8):1697-700.

27. Yu CM, Chen $\mathrm{CH}$, Liu HT, Dai MH, Wang IC, Wang KC. Subacromial injections of

corticosteroids and xylocaine for painful subacromial impingement syndrome. Chang Gung Med J. 2006 Sep-Oct;29(5):474-9.

28. Gunter P, Schwellnus MP. Local corticosteroid injection in iliotibial band friction syndrome in runners: a randomised controlled trial. Br J Sports Med. 2004 Jun;38(3):269-72; discussion 72.

29. Shrier I, Matheson GO, Kohl HW, 3rd. Achilles tendonitis: are corticosteroid injections useful or harmful? Clin J Sport Med. 1996 Oct;6(4):245-50.

30. Holt MA, Keene JS, Graf BK, Helwig DC. Treatment of osteitis pubis in athletes. Results of corticosteroid injections. Am J Sports Med. 1995 Sep-Oct;23(5):601-6.

31. Assendelft WJ, Hay EM, Adshead R, Bouter LM. Corticosteroid injections for lateral epicondylitis: a systematic overview. $\mathrm{Br} \mathrm{J}$ Gen Pract. 1996 Apr;46(405):209-16.

32. Smidt N, van der Windt DA, Assendelft WJ, Deville WL, Korthals-de Bos IB, Bouter LM.

Corticosteroid injections, physiotherapy, or a wait-and-see policy for lateral epicondylitis: a randomised controlled trial. Lancet. 2002 Feb 23;359(9307):657-62.

33. Michael RH, Holder LE. The soleus syndrome. A cause of medial tibial stress (shin splints). Am J Sports Med. 1985 MarApr;13(2):87-94.

34. Detmer DE. Chronic shin splints. Classification and management of medial tibial stress syndrome. Sports Med. 1986 NovDec;3(6):436-46.

35. Nissen LR, Astvad K, Madsen L. [Lowenergy laser therapy in medial tibial stress syndrome]. Ugeskr Laeger. 1994 Dec 5;156(49):7329-31.

36. Mubarak SJ, Gould RN, Lee YF, Schmidt DA, Hargens AR. The medial tibial stress syndrome. A cause of shin splints. Am J Sports Med. 1982 Jul-Aug;10(4):201-5.

37. Beck BR, Osternig LR. Medial tibial stress syndrome. The location of muscles in the leg in relation to symptoms. J Bone Joint Surg Am. 1994 Jul;76(7):1057-61.

38. Saxena A, O'Brien T, Bunce D. Anatomic dissection of the tibialis posterior muscle and its correlation to medial tibial stress syndrome. J Foot Surg. 1990 Mar-Apr;29(2):105-8.

39. James T. Chronic lower leg pain in sport. Aust Fam Physician. 1988 Dec;17(12):1041-5.

40. Holen KJ, Engebretsen L, Grontvedt $T$, Rossvoll I, Hammer S, Stoltz V. Surgical treatment of medial tibial stress syndrome (shin splint) by fasciotomy of the superficial posterior compartment of the leg. Scand J Med Sci Sports. $1995 \mathrm{Feb} ; 5(1): 40-3$.

41. Abramowitz AJ, Schepsis A, McArthur C. The medial tibial syndrome. The role of surgery. Orthop Rev. 1994 Nov;23(11):875-81.

42. Gottlieb NL, Riskin WG. Complications of local corticosteroid injections. Jama. $1980 \mathrm{Apr}$ 18;243(15):1547-8.

43. Fricker PA, Taunton JE, Ammann W. Osteitis pubis in athletes. Infection, inflammation or injury? Sports Med. 1991 Oct;12(4):266-79.

Rev. lb. Cᄃ. Act. Fis. Dep. 